\title{
Laporan Kasus Avian Influenza di Dusun Cabean, Kelurahan Mangunsari, Kecamatan Sidomukti, Kota Salatiga Tahun 2019
}

\author{
Case Report of Avian Influenza at Cabean, Mangunsari Village, \\ Sidomukti Sub-district, Salatiga City in 2019
}

\author{
Meta Iqomah \\ Dinas Pertanian Kota Salatiga \\ *E-mail : metamumuz@gmail.com
}

\begin{abstract}
ABSTRAK
Virus Avian Influenza (AI) dibedakan menjadi Low Pathogenic Avian Influenza (LPAI) dan High Pathogenic Avian Influenza (HPAI) dimana pada HPAI ditunjukkan dengan tingkat kematian unggas yang mencapai 100\% dalam waktu yang singkat. Tujuan dari penelitian terhadap kematian unggas di Cabean, kelurahan Mangunsari, Kecamatan Sidomukti, Kota Salatiga adalah untuk mengidentifikasi penyebab kematian dan menentukan tindakan pengendalian. Observasi dilakukan pada tanggal 29 Juli 2019 hingga 3 Agustus 2019 dan analisis data dilakukan secara deskriptif. Informasi kematian mendadak pada unggas dilaporkan pemilik pada 29 Juli 2019. Dalam satu minggu kematian ayam kampung mencapai 38,75\%, itik manila (entok) mencapai 90\% dan angsa mencapai $100 \%$. Dari hasil pemeriksaan berdasarkan informasi, nekropsi, rapid test dan laboratorium, dapat disimpulkan bahwa kematian mendadak pada unggas yang terjadi di Cabean disebabkan oleh virus Avian Influenza. Hasil investigasi diharapkan mampu memberikan kejelasan penyebab kematian unggas dan pemahaman kepada masyarakat terutama peternak unggas mengenai virus Avian Influenza, tindak pencegahan dan penanggulangannya.
\end{abstract}

Kata Kunci: Avian Influenza, penyakit unggas, unggas, Salatiga

\begin{abstract}
Avian Influenza (AI) viruses are divided into Low Pathogenic Avian Influenza (LPAI) and High Pathogenic Avian Influenza (HPAI) where on HPAI it is indicated by poultry mortality reaching $100 \%$ in a short time. The purpose of reseaching poultry death in Cabean, Mangunsari village, Sidomukti, Salatiga is to identify the cause of the death and determine control measures. The observation was carried out on 29 July 2019 to 3 August 2019 and data analysis was carried out descriptively. Information on sudden death in poultry was reported by the owner on July 29,2019 . Within one week the death of free-range chicken was $38.75 \%$, manila duck was $90 \%$, and geese was $100 \%$. From the results of investigations, based on information, necropsy, rapid test and laboratories, it can be concluded that the sudden death of poultry that occurred in Cabean was caused by Avian Influenza virus. This investigation is expected to be able to provide the occuracy
\end{abstract}


of cause of the sudden death and an understanding to the public, especially poultry farmers about the Avian Influenza virus, its prevention and precautions.

Keyword: Avian Influenza, poultry disease, poultry, Salati

\section{PENDAHULUAN}

Salatiga adalah kota kecil di provinsi Jawa Tengah, mempunyai luas wilayah $\pm 56,78 \mathrm{~km}^{2}$, terdiri dari 4 kecamatan, 22 kelurahan, berpenduduk 176.795 jiwa. Terletak pada jalur regional Jawa Tengah yang menghubungkan kota regional Jawa Tengah yang menghubungkan kota Semarang dan Surakarta. Meski dikenal sebagai kota kecil, Kota Salatiga memiliki potensi di sektor peternakan, salah satunya adalah unggas, dan kepemilikan ayam buras di skala rumah tangga masih banyak tersebar. Berdasarkan data dari Badan Pusat Statistik (BPS) tahun 2016, populasi ayam buras pada tahun 2015 sebanyak 89.300 ekor, itik 3.956 ekor, burung puyuh 22.000 ekor, ayam ras 371.900 ekor dan itik manila (entok) 6.000 ekor.

$$
\text { Ayam bukan ras (buras) }
$$
merupakan salah satu sumber plasma nutfah yang mempunyai potensi penggerak ekonomi pedesaan dan merupakan ternak unggas yang sangat umum dipelihara di daerah pedesaan. Pemeliharaannya di masyarakat umumnya tidak dengan sistem intensif, kepemilikan tidak dalam jumlah besar (small holder) serta program biosekuriti dan vaksinasi tidak selalu diterapkan. Kandang, pakan yang cukup, dan faktor kesehatan merupakan hal yang penting dalam pemeliharaan ayam buras. Saat ini penyakit ayam yang masih menjadi perhatian serius adalah Avian Influenza (Suwito et al., 2013).

Unggas lain yang rentan terhadap Avian Influenza adalah golongan unggas air seperti entok dan angsa. Di Indonesia pemeliharaan ternak entok masih dilakukan secara ekstensif serta belum mendapat perhatian serius (Lase dan Lestari, 2020). Demikian juga dengan angsa, dimana angsa (putih) adalah jenis angsa yang paling banyak dibudidayakan di rumah karena kemudahan dalam pemeliharaannya (NN, 2021). Unggas air merupakan reservoir semua subtipe virus Influenza A, tetapi secara umum tidak menunjukkan gejala klinis, namun unggas air dapat menularkan virus ke ayam dan menyebabkan akibat yang fatal (Tumpey et al., 2002). Populasi yang tinggi dan sistem penggembalaan unggas air secara bebas dianggap sebagai faktor-faktor yang turut berperan dalam memperbesar potensi unggas air sebagai reservoir virus AI H5N1 di Indonesia (Hewajuli dan Dharmayanti, 2012)

AI merupakan penyakit infeksi akut yang disebabkan oleh virus influenza tipe A, dapat menyerang beberapa jenis unggas dengan angka mortalitas yang tinggi. Berdasarkan patotipenya, virus AI dibedakan menjadi Highly Pathogenic Avian Influenza (HPAI) atau tipe ganas dan Low Pathogenic Avian Influenza (LPAI) atau tipe kurang ganas. Tanda yang paling menciri untuk HPAI adalah tingkat kematian yang tinggi yang mencapai 100\% (Kementan, 2014)

Tujuan penelitian terhadap kematian unggas di Cabean, kelurahan Mangunsari, Kecamatan Sidomukti, Kota Salatiga adalah untuk mengidentifikasi penyebab kasus kematian unggas dan menentukan langkah-langkah pengendalian.

\section{METODE PENELITIAN}

\section{Deskriptif}

Metode ini menjelaskan kasus yang terjadi berdasarkan definisi kasus, suspect kasus dan konfirmasi yang di dapat. Defenisi kasusnya adalah 
kematian unggas secara mendadak tanpa gejala dan dengan gejala.

Waktu pelaksanaan dan Pengumpulan informasi

Penyidikan kematian unggas yang terjadi di Cabean, kelurahan Kecandran, Kecamatan Sidomukti dilaksanakan tanggal 29 Juli 2019 hingga 3 Agustus 2019 dengan melakukan pengumpulan informasi dari peternak, pengambilan sampel, oleh Dinas Pertanian Kota Salatiga dirujuk ke Balai Veteriner Keswan Propinsi Jawa Tengah, pengujian dengan rapid tes dan dengan melaksanakan Komunikasi, Informasi dan Edukasi (KIE) tentang AI kepada peternak dan warga Cabean.

\section{Pengambilan Spesimen}

Pengambilan sampel dilakukan oleh Dinas Pertanian Kota Salatiga berdasarkan informasi dan tanda tanda klinis. Pemeriksaan yang dilakukan adalah nekropsi bangkai dan uji cepat (rapid tes) dan merujuk ke Balai Veteriner Keswan Propinsi Jawa Tengah adalah nekropsi bangkai, pengujian serologis dan Polymerase Chain Reaction (PCR) di Balai Veteriner Keswan Propinsi Jawa Tengah terhadap sampel organ.

\section{Analisis data}

Analisa data dilakukan secara deskriptif dengan cara mendeskripsikan data yang terkumpul dan pengolahan data sebagaimana adanya. Pengumpulan data dilakukan berdasarkan informasi kematian dari pelapor dengan gejala-gejala yang nampak. Pengolahan data atas data yang terkumpul dengan melakukan nekropsi, rapid test dan PCR.

\section{HASIL DAN PEMBAHASAN}

Informasi kematian mendadak pada unggas dilaporkan oleh pemilik pada tanggal 29 Juli 2019. Jumlah kepemilikan yaitu ayam buras sebanyak 80 ekor (dewasa dan anakan), entok sebanyak 40 ekor (dewasa dan anakan), angsa sebanyak 4 ekor (dewasa) dan burung puyuh sebanyak 1000 ekor (akan afkir). Unggas tidak ada yang di vaksin serta di pelihara dalam kandang dan di luar kandang (umbaran/backyard). Berdasakan informasi, kematian mendadak pertama kali terjadi pada tanggal 28 Juli 2019 tanpa ada gejala. Gejala gangguan pernafasan muncul pada tanggal 1 Agustus 2019 saat petugas melakukan tinjauan lapangan kedua untuk pengambilan spesimen dan rapid tes. Gejala tortikolis juga ditemukan pada entok tapi tidak pada ayam. Pada itik, gejala klinis dari serangan AI yang muncul mirip dengan penyakit Newcastle Disease (ND) seperti tortikolis, lumpuh, dan kejang/gemetar (NN, 2016) namun itik dewasa umunya telah mengandung antibodi terhadap ND dalam darahnya (Kementan, 2014). Unggas juga mengalami diare kehijauan. Kematian awal terjadi pada unggas-unggas umbaran. Kematian berikutnya juga terjadi pada unggas yang ada didalam kandang. Gejala klinis infeksi virus AI biasanya pada saluran pernafasan, gastro-intestinal dan susunan syaraf (Hewajuli dan Dharmayanti, 2008). Dilansir dari Direktorat Jenderal Peternakan dan Kesehatan Hewan (Ditjen PKH) bahwa pada bulan Januari-September tahun 2017 kejadian kematian unggas karena AI terjadi pada itik/bebek, broiler, puyuh, ayam kampung, layer, dan kalkun. Jumlah terbanyak adalah jenis itik/bebek (Permatasari, 2018).

Tabel 1. Akumulasi kematian unggas dalam 7 (tujuh) hari pertama

\begin{tabular}{|c|c|c|c|c|}
\hline \multirow{2}{*}{ Tanggal } & \multicolumn{2}{|c|}{$\begin{array}{c}\text { Jumlah Kematia } \\
\text { (ekor) }\end{array}$} & \multicolumn{2}{|c|}{ Keterangan } \\
\hline & $\begin{array}{l}\text { Ayam } \\
\text { Buras }\end{array}$ & Entok & Angsa & \\
\hline $\begin{array}{l}\text { 28\&29-7- } \\
2019\end{array}$ & 4 & 10 & 4 & $\begin{array}{l}\text { Tanpa } \\
\text { gejala }\end{array}$ \\
\hline $31-7-2019$ & 12 & 19 & - & $\begin{array}{l}\text { Yang } \\
\text { masih } \\
\text { hidup }\end{array}$ \\
\hline
\end{tabular}




\begin{tabular}{|c|c|c|c|c|}
\hline & & & & $\begin{array}{l}\text { ada gejala } \\
\text { gangguan } \\
\text { pernafasa } \\
\mathrm{n} \text { dan } \\
\text { terjadi } \\
\text { diare }\end{array}$ \\
\hline $1-8-2019$ & 3 & 1 & - & \\
\hline 2-8-2019 & 3 & 3 & - & \\
\hline $3-8-2019$ & 6 & 3 & - & \\
\hline Total & 31 & 36 & 4 & \\
\hline Kematian & $\begin{array}{c}(38,75 \\
\%)\end{array}$ & $(90 \%)$ & $(100 \%)$ & \\
\hline
\end{tabular}

Dari data jumlah kematian total (3 jenis unggas) dapat diketahui angka kematian dalam 7 hari adalah 57,23\% (71 ekor dari total populasi 124 ekor). Pada tanggal 8 Agustus 2019, diinformasikan oleh peternak bahwa unggas mati secara keseluruhan. Nekropsi dilakukan di Dinas Pertanian Kota Salatiga pada tanggal 31 Juli 2019. Nekropsi dilakukan pada unggas entok dan ayam buras.

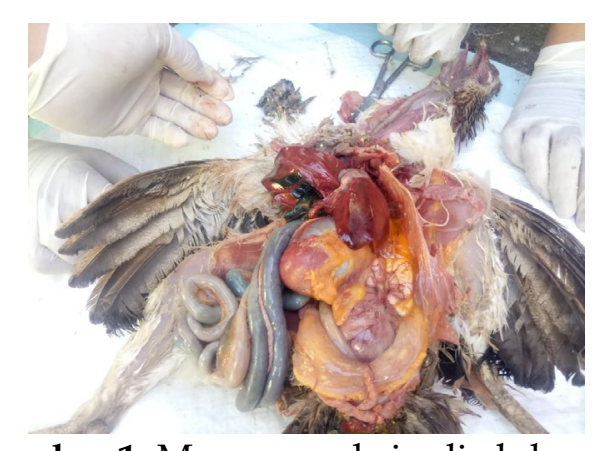

Gambar 1. Masa mengkeju di abdomen, bentuk telur muda tidak beraturan (ayam buras)

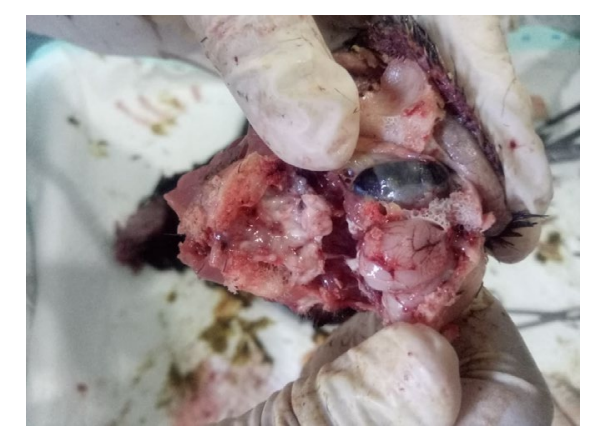

Gambar 2. Hemoragi pada otak (ayam buras)

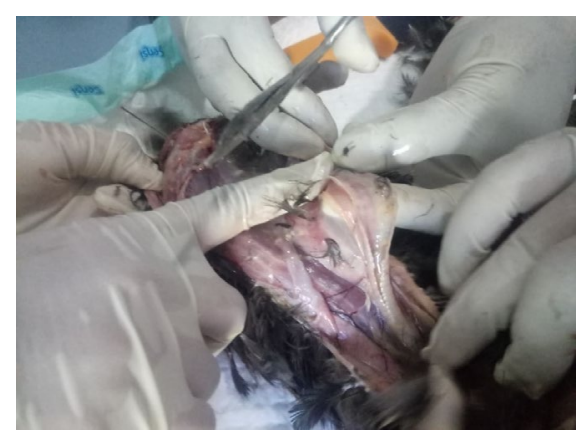

Gambar 3. Lendir pada trachea (ayam buras)

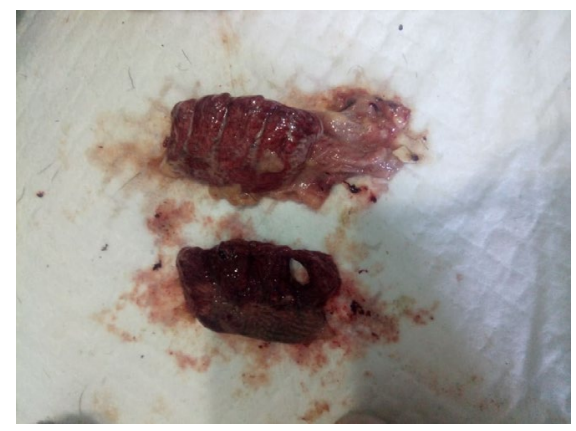

Gambar 4. Hemoragi pada paru-paru (ayam buras)

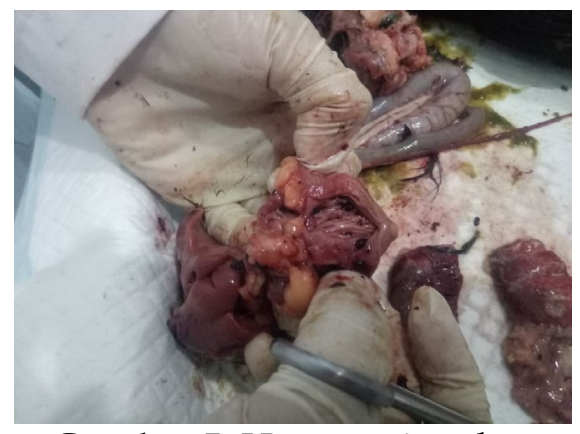

Gambar 5. Hemoragi pada proventriculus (ayam buras)

Gambaran nekropsi juga ditemukan pada investigasi yang dilakukan Oktarianti et al. (2018) dimana ditemukan masa mengkeju pada abdomen, pendarahan pada paruparu, dan pendarahan di proventrikulus. Rapid test dilakukan pada tanggal 1 Agustus 2019 berupa swab kloaka dan orofaring dari 2 (dua) ekor ayam buras dan 2 (dua) ekor entok. Rapid test menunjukkan hasil positif dengan munculnya 2 (dua) garis merah pada alat. 


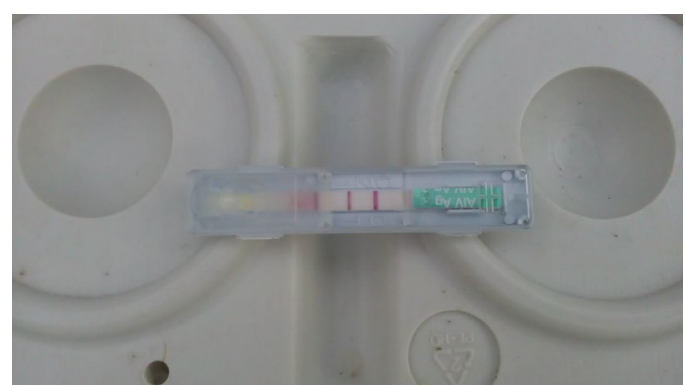

Gambar 6. Hasil rapid test (dua garis merah)

Gejala klinis dan perubahan patologi yang ditimbulkan oleh AI sangat bervariasi. Sehingga AI mempunyai diagnosis banding dengan beberapa penyakit lain diantaranya ND, Infectious Laringotracheitis, Fowl Plaque, Fowl Cholera dan penyakit sistemik lainnya. Meski hasil nekropsi dan rapid test merujuk pada kejadian AI, penegakan diagnosa dengan pemeriksaan laboratorium perlu dilakukan untuk menentukan diagnosa definitif (Hewajuli dan Dharmayanti, 2008) dan memberikan kepastian kepada pemilik dan warga sekitar, terutama yang juga memiliki unggas.

Spesimen untuk penegakan diagnosa di proses di Laboratorium Kesehatan Hewan Kota Semarang, Balai Veteriner Semarang, Dinas Peternakan dan Kesehatan Hewan Provinsi Jawa Tengah. Spesimen bangkai ayam buras 1 ekor untuk dilakukan nekropsi dan Tes PCR terhadap organ paru-paru. Hasil nekropsi menunjukkan perubahan pada organ pernafasan. Nostril dan trachea berlendir dan terdapat cairan di rongga paru-paru sedangkan tes PCR menunjukan hasil positif terhadap AI. Spesimen serum darah dari 2 ekor ayam buras dan 3 ekor entok dilakukan pengujian serologis (Hemaglutinasi Inhibition/HI) terhadap AI, ND, Pullorum, dan Mycoplasma. Untuk uji HI pada ayam dan entok tidak ditemukan titer antibodi terhadap AI tapi ditemukan titer antibodi terhadap ND. Hasil uji juga menunjukkan positif terhadap Salmonella namun hasil ini hanya ditemukan pada spesimen serum ayam buras dan negatif terhadap Mycoplasma.

Berdasarkan data, nekropsi, rapid test dan laboratoris, dapat disimpulkan kematian unggas mendadak yang terjadi di Cabean disebabkan oleh virus AI dan disertai dengan infeksi Salmonella. Pemeriksaan laboratorium (PCR) belum mampu mengidentifikasi strain dari virus AI. Namun melihat dari mortalitas yang mencapai 100\%, dalam waktu 12 hari, bisa ditarik kesimpulan bahwa penyebab kematiannya adalah virus High Pathogenic Avian Influenza (HPAI). Tingkatan infeksi HPAI merupakan infeksi yang sangat patogen yang dapat menyebabkan angka kematian sampai $100 \%$ (Helmi, dkk. 2016). Sedangkan infeksi Low Pathogenic Avian Influenza (LPAI) diketahui menyebabkan morbiditas tinggi $(>50 \%)$ dan mortalitas rendah $(<5 \%)$, tetapi laju mortalitas dapat sangat tinggi jika disertai dengan infeksi patogen sekunder atau LPAI menginfeksi unggas muda (Swayne dan Pantin-Jackwood, 2008).

Tindakan pencegahan penyebaran dan penanggulangan yang dilakukan oleh Dinas Pertanian Kota Salatiga diawali dengan KIE kepada pemilik dan warga sekitar kejadian, optimalisasi penerapan biosekuriti terutama pada kandang lokasi kejadian dan lokasi sekitar dimana warga sekitar banyak yang memiliki unggas dalam jumlah kecil (small holder) melalui penyemprotan desinfektan, penyemprotan desinfektan secara massal oleh Dinas Pertanian dilakukan pada tanggal 8 Agustus 2019, vaksinasi AI secara terprogram dan mempercepat pelaporan kejadian kematian unggas.

\section{KESIMPULAN}

Kematian unggas di Cabean mencapai $100 \%$ pada hari ke-12 (dari tanggal 28 Juli 2019 hingga 8 Agustus 2019) dengan gejala pernafasan dan pencernaan pada sebagian unggas. 
Nekropsi menunjukkan perubahan patologis yang mengarah ke AI yaitu adanya perdarahan pada proventrikulus dan paru-paru, cairan pada rongga paru-paru, lendir pada nostril dan trachea, dan masa mengkeju pada abdomen serta bentuk telur muda yang tidak beraturan. Hasil positif terhadap virus Avian Influenza ditunjukkan dengan rapid test dan PCR. Berdasarkan keseluruhan data yang diperoleh, hasil nekropsi, rapid test dan pemeriksaan laboratorium metode PCR, penyebab kematian unggas di dusun Cabean, kelurahan Mangunsari, kecamatan Sidomukti, Kota Salatiga adalah virus AI.

\section{UCAPAN TERIMA KASIH}

Penulis mengucapkan terima kasih kepada Bidang Peternakan dan Kesehatan Hewan Dinas Pertanian Kota Salatiga dan Laboratorium Kesehatan Hewan Kota Semarang, Balai Veteriner Semarang, Dinas Peternakan dan Kesehatan Hewan Provinsi Jawa Tengah yang telah membantu dalam penelitian ini.

\section{DAFTAR PUSTAKA}

Badan Pusat Statistik (BPS). 2016. Populasi Unggas di Kota Salatiga Tahun 2002-2015.

https://salatigakota.bps.go.id.

Helmi, T.Z., C.R. Tabbu, W.T. Artama,

A. Haryanto dan M. Isa. 2016. Isolasi dan Identifikasi Virus Avian Influenza pada Berbagai Spesies Unggas Secara Serologis dan Molekuler. Jurnal Kedokteran Hewan. Vol. 10. No. 1.

Hewajuli, D.A dan N.L.P.I. Dharmayanti. 2008. Karakterisasi dan Identifikasi Virus Avian Influenza (AI). Balai Besar Penelitian Veteriner. Bogor.

Hewajuli, D.A dan N.L.P.I. Dharmayanti. 2012. Hubungan AI dan Unggas Air dalam Menciptakan Keragaman Genetik Serta Peran
Unggas Air Sebagai Reservoir Pada Penyebaran Virus AI. Balai Besar Penelitian Veteriner. Bogor

Kementerian Pertanian. 2014. Manual Penyakit Unggas cetakan ke-2. Jakarta: Kementerian Pertanian.

Lase, J.A dan D.Lestari. 2020. Potensi Ternak Entok (Cairina Moschata) Sebagai Sumber Daging Alternatif Dalam Mendukung Ketahanan Pangan Nasional. Seminar Nasional dalam Rangka Dies Natalis ke-44 UNS Tahun 2020 "Strategi Ketahanan Pangan Masa New Normal Covid-19"

NN. 2016. Pengendalian Penyakit AI pada Itik. Medion ardhika bhakti. http://info.medion.co.id. Info Medion Edisi September 2016. NN. https://trikmerawat.com/budidaya -angsa-putih/

Oktarianti, E., Efiana, dan B.I. Purnama. 2018. Investigasi Outbreak Avian Influenza Kecamatan Mungka Kabupaten Lima Puluh Kota Tahun 2018. Oral Presentation. AEVI-9.

Permatasari, I. 2018. Situasi Kejadian Avian Influenza (AI) pada Unggas Kondisi Sampai Dengan September 2017.

http:/ / keswan.ditjenpkh.pertanian. go.id/?p=1796

Pracoyo, N.E. 2009. Penyebab Infeksi Avian Influenza A (H5N1) di Indonesia. Jurnal Ekologi Kesehatan. Vol. 8. No. 4.

Pranatha, W.D., R. Irhas, H.N.P. Arihono, N.W.H. Widyasanti, dan I.M. Kardena. 2018. Laporan Kasus New Castle Disease dan Avian Influenza pada Ayam Buras. Indonesia Medicus Veterinus.

Suwito, W., Supriadi, E. Winarti, R.A. Primatika. 2013. Kajian Vaksin Avian Influesa (AI) pada Ayam Buras dengan Sistem Kandang Kurung di Gunung Kidul Yogyakarta. Sains Peternakan. Vol. $11(2)$. 
Swayne, D.E and M. Pantin-Jackwood. 2008. Pathobiology of avian influenza virus infections in birds and mammals. Iowa, USA: Blackwell Publishing Professional.

Tumpey, T.M., D.L Suarez, L.E.L. Perkins, D.A. Senne, L. Jae-Gil, L. Youn-Jeong, M. In-Pil, S. HaanWoo, D.E. $\quad$ Swayne. 2002. Characterization of a highly pathogenic $\mathrm{H} 5 \mathrm{~N} 1$ avian influenza A virus isolated from duck meat. Jun;76(12):6344-55.
Wibawa, H., Lestari, H. Mulyawan dan I. Pramastuti. 2015. Avian Influenza Subtipe H5 : Aras Infeksi Penyakit dan Faktor-faktor yang Beresiko dalam Penularan Virus H5 pada Itik di Jawa Timur, Jawa Tengah dan Daerah Istimewa Yogyakarta Tahun 2014. Buletin Laboratorium Veteriner. Balai Besar Veteriner Wates. Volume 15. Tahun I. 